\title{
Improvement work as a coursework requirement in nursing training can improve nursing competence
}

\author{
Solveig Sægrov* \\ Western Norway University of Applied Science, Førde, Norway
}

Received: May 2, 2017

DOI: $10.5430 /$ jnep.v7n12p132
Accepted: July 5, 2017

Online Published: August 22, 2017

\begin{abstract}
Objective: Nursing students must acquire the competence to work as nurses in a health service that is complex and where improvements can prove demanding. The purpose of the study is to examine how students' coursework requirement in improvement work is performed in practice and whether it improves nursing competence.

Methods: This is a single case study based on an interview with one student.

Results and conclusions: During the study it emerged that students' improvement work in nursing practice is an instructive and interesting process and that as such will contribute to providing patients with better nursing care. It also emerged that a student can find it difficult to raise an issue that ought to be improved in practice. The informant emphasized that it was important to be taken seriously when one suggested new measures for improvement. Having sufficient time to complete the improvement process would improve overall competence.
\end{abstract}

Key Words: Improvement work, Coursework requirement, Nursing competence, Nursing education

\section{INTRODUCTION}

The purpose of this single case research project is to examine how a student's coursework requirement in improvement work is performed in practice and whether it improves nursing competence. Accordingly, the research question has been: How can a coursework requirement in improvement work improve the competence of qualified nurses and their practice?

By nursing competence is meant that students are professionally qualified and perform their profession in accordance with current laws, regulations and professional guidelines. ${ }^{[1]}$ The ability to practice knowledge-based practice is to make professional decisions based on systematically obtained research-based knowledge, experience-based knowledge, and the patient's wishes and needs in a given situa- tion. ${ }^{[2]}$

The health service is complex, and improving it can prove demanding. The model for quality improvement may help to ensure the necessary systematics. Systematic improvement work is a continual process based on a model with five main factors: 1) preparation, 2) planning, 3) performance, 4) evaluation and 5) follow-up. These factors can serve as a checklist to ensure successful implementation of quality improvement. ${ }^{[3]}$ It is important that undergraduate nursing students both receive training in and perform improvement work during their training.

Deming's Out of Crises ${ }^{[4]}$ was a bestseller and remains a classic text written by one of the foremost quality improvement experts of the 20th century ${ }^{[5]}$ Deming saw innovation as only one component of a set of overarching principles

\footnotetext{
*Correspondence: Solveig Sægrov, Associate professor; Email: Solveig.Segrov@hvl.no; Address: Western Norway University of applied Science, Førde, Norway
} 
of improvement, and the innovation that he maintained was essential process improvement. However, despite pockets of activity, quality improvement training and expertise has been slow to be adopted in health services. ${ }^{[6]}$

Learning and developmental opportunities can be planned, but it is the individuals participating in the learning processes who, in interaction with their environment, determine the outcome. ${ }^{[7]}$ In a systematic review of hand hygiene $(\mathrm{HH})$ improvement strategies: a behavioural approach ${ }^{[8]}$ they concluded that by focussing on determinants of behaviour change, they found hidden and valuable components in $\mathrm{HH}$ improvement strategies. Drawing on previously acquired knowledge in new situations can result in important new knowledge. ${ }^{[9-11]}$ Benner and Sutphen ${ }^{[9]}$ presume that, to be able draw on the most scientific theory, one must focus on how, as a nursing student, one perceives specific clinical situation. As a professional education consisting of theoretical and clinical studies, nursing education has the opportunity to give nursing students insights into the variety of knowledge sources needed in work environment. ${ }^{[12]}$

Several authors have highlighted the role of intuition in expertise. In particular, a large amount of data has been collected about intuition in expert and nursing, and intuition plays an important role in the influential theory of nursing expertise developed by Benner ${ }^{[13]}$ from Novice to Expert. For example Benner ${ }^{[13]}$ recommends that analytical and abstract methods should be thought beginners, but not in later stages, where instruction should focus on developing intuitive skills through direct interaction with concrete examples of patients.

In connection with communities of practice, the nature and challenges of the work and the level of autonomy are examples of typical conditions for learning and using knowledge in professional practice. ${ }^{[14,15]}$ Through acquiring experience, the professional practitioner will also develop her thinking and actions. ${ }^{[16]}$ Professional learning will always involve actively participating in one's own learning. ${ }^{[17]}$

\section{Method}

\subsection{Design and method}

This is a single case study that was conducted in the spring of 2015. The research method involves an in-depth analysis of one interview. A case study is an empirical study of a phenomenon in depth and inside its real-world contact. ${ }^{[18]}$ "There's no formula, but your choice depends in large part on your research question(s). The more that your questions seek to explain some present circumstance (e.g. 'how' or 'why' some social phenomenon works), the more that case study research will be relevant." [19] "A case study places high demands on the researcher to explain where a narrative be- longs in a wider context." ${ }^{[20]}$ Case study researchers attempt to analyse and understand issues that are important to the history, development, or circumstances of entity under study. ${ }^{[21]}$ A single - case study is an appropriate design when (1) it is a critical case in testing a well formulated theory, (2) it represents an extreme or unique case, (3) it is a representative or typical case, (4) it is a revelatory case, and (5) it is a longitudinal case. ${ }^{[19]}$

Although understanding a particular case is the central concern of case studies, they are sometimes a useful way to explore phenomena that have not been rigorously researched. The information obtained in case studies can be used to develop hypotheses to be tested more rigorously in subsequent research. ${ }^{[21]}$ Furthermore, case studies may serve the important role of clarifying concepts or of elucidating ways to capture them.

The interview is based on a completed coursework requirement in improvement work during the final practice period, entitled "Preparation for life in the workplace", in the bachelor's degree programme in nursing. The practice period lasted for six weeks. The coursework requirements must be based on a topic chosen by the student through observation in practice and in cooperation with the practice placement. This coursework requirement must also be presented in written and oral form to the personnel at the practice placement. The questions and topics in the interview guide were based on the programme description for the bachelor programme in nursing, in accordance with the National Curriculum Regulations of 2008 stated in the Act relating to Universities and University Colleges ${ }^{[1]}$ theory in improvement work and learning outcomes from coursework requirements in improvement work, theory of knowledge and in learning and change in organisations.

\subsection{Sample}

An invitation was extended to participate in focus-group interviews with representatives from the field of practice and students who had recently completed a coursework requirement in improvement work. One student attended the interview, and had given prior consent. Preparations for the interview were made as if it were a focus-group interview, and the project manager decided to conduct the interview as $\mathrm{N}=1$. An interview guide was prepared. This interview was so thorough and good that the researcher decided not to conduct further interviews.

\subsection{Data collection}

The background was to try to identify experiences of nursing practice as an arena for student improvement work and what competencies students can gain as qualified nurses. Since 
only one representative attended, he was first asked if it was acceptable to conduct the interview as the only representative, and he agreed. The representative was issued with the interview guide to read before the interview commenced. According to Polit and Beck, ${ }^{[21]}$ qualitative researchers do not identify an explicit population that can be generalised, but instead find individuals who are eligible to participate in the research. One research question was formulated: "How can a coursework requirement in improvement work improve the competence of qualified nurses and their practice?" After the research question was read out, an opportunity was given for spontaneous response. The respondent held on to the interview guide throughout the interview, which contained four topics and room for final comments. Based on the research question, the following research topics were set out: 1) Cooperation and facilitation, with two subtopics; 2) Nursing competence, with four subtopics; 3) Implementation, with two subtopics; and 4) Time aspect, with two subtopics. The interview was recorded on tape and lasted one hour. The interview went quickly due to the level of engagement and concentration on the part of the informant and researcher. When the informant was asked for any final comments, he said: "I feel that the research question you have formulated reflects these questions."

\subsection{Analysis}

The interview was recorded on tape and was transcribed verbatim shortly after. A qualitative hermeneutic content analysis was performed to identify the main findings and thematic patterns. ${ }^{[21]}$ The purpose of a hermeneutic interpretation is to gain a valid general understanding of the textual meanings. ${ }^{[22]}$ Kvale's $^{[23]}$ three levels of interpretation were followed: self-understanding, critical understanding based on common sense and theoretical understanding. The first level, self - understanding, is the informant's statement. The second level, critical understanding is the researcher's comments to the statements. The interpretation has here a wider understanding than the informant's own interpretation. Theoretical understanding, is the third level, there the theoretical framework and research results from other research try to extend the perspective. Here the theory about learning and competence show how the connection with student's coursework requirement in improvement work improves nursing competence.

The first time the transcribed text was read in search of meaning of the text as a whole, the result was provisionally themes, as also had their source in the interview guide and the intention with the study. ${ }^{[23]}$ Next, the Manus was read through to systematize the text to find out the main categories. Further the researcher do one theoretical interpretation by putting the categories together in meaningful units. The analysis showed that the interview and discussions naturally followed the four topics set out in the interview guide and that the informant had responded to each topic and subtopic. A final decision was made about which statements should be selected to elucidate each topic. Accuracy in conducting the research process is essential to achieving reliability and validity. ${ }^{[24]}$

\section{Findings}

Four topics emerging from the interview are presented, along with statements selected to elucidate the each topic: 1) Cooperation and facilitation; 2) Nursing competence; 3) Implementation; and 4) Time aspect.

\subsection{Cooperation and facilitation}

According to the programme description, the students must observe and find topics in practice that ought to be improved. The students must select a topic in cooperation with the practice placement. The informant said that the practice placement could improve facilitation by highlighting areas for improvement work and that cooperation would then also be improved in respect of implementation.

"Well, it has something to do with it being a bit difficult to pick out things in a work group when you don't know the members very well; that you can be afraid of being distrusted. So it would have been much better for both parties if everyone knew what was going to happen, and no one would have felt they were being attacked in any way."

"Cooperation between some practice placements and students could perhaps be improved by finding a topic we could work on and maybe also in terms of performance; that the workplace could cooperate on carrying it out, on realising it, if that was appropriate."

\subsection{Nursing competence}

Improvement work is a coursework requirement intended to enhance the competence of qualified nurses. The informant clearly conveyed that he wanted to take what he learned through the coursework requirement with him in his future nursing practice, and that it might therefore be beneficial to patients:

"I think it was an instructive and interesting process, where I had to find a topic and find research literature on it, see if I could find out what might be better practice. So I would say that it was instructive and that I will be able to use it in my future nursing practice." 


\subsection{Implementation}

The informant realised that after he had put forward his suggestion for improvement to the practice placement, they would have to discuss whether it was something the practice placement wanted to try out, and then the entire workplace had to be involved. If not, it would not have any real effect:

"It's quite important that there is a common understanding that the students must perform improvement work. If not, students will feel that they are not being taken seriously and perhaps feel that the whole idea of improvement work was a waste of effort."

"So if research has been done on the topic, it may support the idea you might have, and therefore prove that this is good practice, and we should also do it to give our patients better service or care or whatever it might be. If it is supported by good research, then I think it's even more relevant to implement it in practice."

\subsection{Time aspect}

Improvement work and practice each have their own assessment criteria. These must be completed in six weeks. The student realised that there was a lot to read and learn at the practice placement, and that a lot had to be given lower priority because of the improvement work. This took too much time given the length of the practice period:

"We are a long way into our practice period when we are presented with the coursework requirement, so we had little opportunity to follow up anything whatsoever, and had to delegate work to others. You don't get to see the entire process. I think that in general competence would improve if we could see the entire process."

\subsection{Final comments}

"I think that in principle improvement work is a good thing. It's important to keep in mind that we must always work at becoming better nurses. I think it's important that the practice placement is clearly told that we must do improvement work and that they react positively to that. That would make it a lot easier for students to carry it out and put it into practice too."

\section{Discussion}

It emerged from the case study that students' improvement work in nursing practice is instructive and that as such will contribute to providing patients with better nursing care. The informant thought the student's coursework requirement work was an interesting process, where he had to find a topic and find research literature on it, see if he could find out what might be better practice.

Therefore, the student said that it was instructive and that he would be able to use the improvement work in his future nursing practice. Deming saw innovation as only one component of a set of overarching principles of improvement, and the innovation that he maintained was essential process improvement. ${ }^{[6]}$ Since the result is based on one interview, it is assumed that the informant represents other students, and that the nature of the individual narrative contained knowledge that offered insight into conditions outside oneself. ${ }^{[25]}$ It emerged from the interview that it can be difficult for a student to suggest a topic that ought to be improved in practice, and that cooperation might have been better if the practice placement had suggested a topic they wanted to improve. This aligns with Klev and Levin's ${ }^{[7]}$ assertion that learning and developmental opportunities can be planned, but it is the people who participate in the learning processes who, through interaction with their workplace environment, determine the outcome. Drawing on previously acquired knowledge in new settings can result in new, important knowledge. ${ }^{[9,11]}$ It also emerged that it is important to learning that the student and the practice placement discuss suggestions for new measures based on the improvement work, and that measures are implemented. It is important to be taken seriously, otherwise the student will feel that the improvement work was a waste of effort. As a professional education consisting of the theoretical and clinical studies, nursing education has the opportunity to give nursing students insights into the variety of knowledge sources needed in work environment. ${ }^{[12]}$

The informant emphasized that in general his competence would have improve if he had had enough time in practice to implement the entire improvement process. Professional learning will always involve actively participating in one's own learning. ${ }^{[17]}$ The ability to practice knowledge-based practice is to make professional decisions based on systematically obtained research - based knowledge, experience-based knowledge, and the patient's wishes and needs in a given situation. ${ }^{[2]}$

\section{Limitations}

"Perhaps the biggest concern about case studies is generalizability: If researchers discover important relationships, it is difficult to know whether the same relationships would occur with others." "21] "[...] the form of the initial research question(s) can directly influence the strategies used in striv- 
ing for external validity."[19] These questions were frequently used in the interview guide, and at the end of the interview the informant said: "I feel that the research question you have formulated reflects the questions in the interview."

\section{CONFLiCTS OF InTEREST Disclosure}

The author declares that there is no conflict of interest.

\section{REFERENCES}

[1] Programme Description for Bachelor Degree Programme in Nursing. in accordance with the Norwegian National Curriculum Regulations for Nursing Education (2008) laid down by the Ministry of Education and Research pursuant to the Act relating to Universities and University Colleges of 1 April 2005 No 15. 2015.

[2] Nortvedt MW, Jamtvedt G, Graverholt B, et al. Jobb kunnskapsbasert! 2012.

[3] Langley G, Moen R, Nolan K, et al. The Improvement Guide: A Practical Approach to Enhancing Organizational Performance. 2nd ed. San Francisco: Jossey -Bass Publishers; 2009.

[4] Deming WE. Out of Crisis. Cambridge, MA: Massachusetts Institute of Technology, Center for Advanced Engineering Study. 1982.

[5] Siriwardena AN. Quality improvement classic. Out of the healthcare crisis. Quality in Primary Care. 2011; 19: 127-31. PMid:21575335

[6] Apekey TA, Mc Sorley G, Tilling M, et al. Room for improvement? Leadership, innovation culture and uptake of Quality improvement methods in general practice. Journal of Evaluation an Clinical Practice. 2010; 17: 311-18. PMid:20438607 https://doi .org/10.1 $111 / j .1365-2753.2010 .01447 . x$

[7] Klev R, Levin M. Forandring som praksis. Endringsledelse gjennom læring og utvikling [Change as Practice: Change Management through Learning and Development]. Fagbokforlaget, Bergen. 2009.

[8] Huis A, van Achterberg T, de Bruin M, et al. A systematic review of hand hygiene improvement strategies: a behavi oural approach. Implementation Science. 2012. Available from: http://www . impl ementationscience.com/content7/1/92

[9] Benner PE, Stephen M. Learning across the professions: The clergy, a case in Point. Journal of Nursing Education. 2007; 46(3): 103-108. PMid: 17396548

[10] Hager P, Smith E. The inescapability of significant contextual learning in work performance. London Review of Education. 2004; 2(1): 33-46. https : //doi .org/10.1080/1474846042000177465

[11] Hager P, Hodkinson P. Moving beyond the metaphor of transfer of learning. British Educational Research Journal. 2009; 35(4): 619-638. https://doi.org/10.1080/01411920802642371

[12] Benner PE, Tanner CA, Chesla CA. Expertise in Nursing Practice: Caring, Clinical Judgment and Ethics. New York: Springer; 2009.
[13] Benner PE. From novice to expert: excellence and power in clinical nursing practice. Menlo Park, Calif.: Adison-Wesley, Menlo Park, California. 1984

[14] Daley BJ. Context: Implications for learning in professional practice. New Direction for Adult and Continuing Education. 2002; 96: 79. https://doi.org/10.1002/ace.81

[15] Eraut M. Expert and expertise: Meanings and perspectives. Learning in Health and Social Care. 2005; 4(4): 173-179. https://doi .or $\mathrm{g} / 10.1111 / \mathrm{j} .1473-6861.2005 .00102 . \mathrm{x}$

[16] Eraut M. Learning contexts. Learning in Health and Social Care. 2006; 5(1): 1-8. https://doi.org/10.1111/j.1473-6861.20 $06.00115 . x$

[17] Løvlie L. 'Dannelse og profesjon' in Kunnskap og dannelse foran et nytt århundre ['Formation and Profession' in Knowledge and formation at the beginning of a new century]. Bolstad, Inga (red.) Oslo: Dannelsesutvalget, Universitetet IOslo; 2009.

[18] Yin RK, Davis D. Adding new dimensions to case study evaluations: The case of evaluating comprehensive reforms. In G. Julnes \& D.J. Rog (eds.), Informing federal policies for evaluation methodology (New Directions in Program Evaluation). San Francisco: Jossey-Bass; 2007.

[19] Yin RK. Case Study Research: Design and Methods. USA: Sage Publications; 2014

[20] Thorne SE. Is the story enough? Qualitative Health Research. 2009; 19: 1183-5. PMid:19690200 https://doi.org/10.1177/1049 732309343951

[21] Polit DF, Beck CT. Nursing Research. Lippincott, Williams and Wilkins. Printed in China. 2012.

[22] Kvale S, Brinkmann S. Interviews. Learning the Craft of Qualitative Research Interviewing. Sage Publications, Inc. Thousand Oaks, California. 2008.

[23] Kvale S. Det kvalitative forskningsintervju [The Qualitative Research Interview]. Ad Notam Gyldendal AS, Oslo. 1997.

[24] Fleming V, Gaidys U, Robb Y. Hermeneutic research in nursing: Developing a Gadamerian-based research method. Nursing Inquiry. 2003; 10(2): 113-120. https://doi.org/10.1046/j.1440-180 $0.2003 .00163 . \mathrm{x}$

[25] Malterud K. Kvalitative metoder i medisinsk forskning [Qualitative Methods in Medical Research]. Universitetsforlaget Oslo. 2011. 